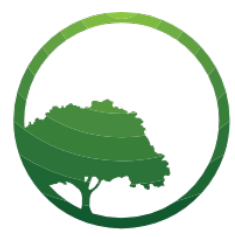

Business \& Social Science IJRBS

\section{Research in Business and Social Science}

IJRBS Vol 8 No 4, ISSN: 2147-4478

Contents available at www.ssbfnet.com/ojs

\title{
Price-Earnings Multiple as an Investment Assessment Tool in Analyzing Stock Market Performance of Selected Universal Banks in the Philippines
}

\author{
Antonio J. Dayag
}

University of Sto. Tomas (UST), Espaňa, Manila

\section{Fernando Trinidad}

University of Sto. Tomas (UST) Graduate School, Espaňa, Manila

\begin{abstract}
Price-Earning Ratio or P/E Multiple is a widely used, straightforward investment assessment tool in developed countries. However, the method has not been utilized as much in stock market performance analysis in developing countries such as the Philippines. Using the top ten universal banks in the country, this paper utilized Price-Earnings Ratio [PER] as valuation tool and dependent variable, and sought to determine its value drivers. Used as independent variables are macroeconomic variables gross domestic product [GDP] growth rate, inflation rate, annual interest rate; stock market index Philippine Stock Exchange [PSEi]; and firm-specific variables return on equity [ROE], growth rate of $R O E$, growth rate of earnings per share, dividend payout ratio [DPO, growth rate of income, and pricebook value [PBV] ratio. Results showed that among the independent variables, ROE, PBV ratio, and PSE index are statistically significant. The model's (R2) is $63.7 \%$, which is a fairly good fit..
\end{abstract}

Key words: Price-earnings Ratio, Universal Banks, Stock Valuation, Bank Valuation, Valuation Tools JEL classification: C23; G32; G21 Submitted: 03.06.2019 - Accepted: 21.06.2019

\section{Introduction}

Business evaluation is an important tool in overcoming economic and financial crisis (Tabara \& Vasiliu, 2011). Business evaluation techniques are needed because the value of an enterprise is changing over time depending on the following aspects: existence of free prices leading to changes in the internal information available to the management of an enterprise in charged with making economic decisions; fluctuations in the exchange ratio, meaning changes in the value of all goods provided and in effect, the value of the total enterprise; internal management of each company in terms of depreciation and accounting policies may lead 
to changing value of enterprise; Chief Executive Officers [CEOs] experiences in terms of staff motivation, employees competence, the strategy applied, the company management structure, size and quality of assets held and used. This makes valuation a highly complex endeavor.

Universal banks play vital roles in economic development because aside from deposit and lending services rendered, other financial services make it possible for businesses and industries to grow. These banks have the components of retail, wholesale, and investment banking that makes transactions more convenient under one roof even if such banks are not necessarily compelled to do so. According to Schildbach (2012), universal banks are recognized to be significantly contributing to a country's financial stability for the following reasons: a) ability to maintain resiliency because of diversified sources of revenues, assets, and liabilities; b) ability to achieve higher profitability due to revenue and cost synergies; c) has greater transparency that helps lower counterparty risks; d) can early detect accumulating systemic risks; and e) can better deal with mismatches in loan-deposits. In effect, investors' trust and confidence in universal banks are higher, compared to typical investment banks. In the Philippines, commercial banks are classified as universal banks, and occupy a huge portion (about 90\%) of the country's banking system's resources (International Trade Administration, 2017).

Pandey (2015) posited that all assets—whether financial or real—can be valued, but the complexities and the details of valuation will vary from case to case. Some analysts used discounted cash flow [DCF] models to value shares, while others used price multiples such as the price-earnings and price-book value ratios. Technical analysts believed that prices were driven as much by investor psychology as by any underlying financial variables. This paper focuses on financial and macroeconomic variables that drive price-earnings ratio [PER] valuation as an important investment tool. PER is mostly used in fundamental analysis of listed and unlisted firms in equity valuation endeavors (Maniar, 2014).

Price-Earnings Ratio [PER] or P/E Multiple is a commonly utilized stock valuation method frequently mentioned in related research papers, academic journals, and on-line articles. It is utilized in "fairness of opinions" among investment bankers in initial public offerings, and a standout amongst the most helpful money related markers for stock valuation. This paper alternately uses the term PER and P/E Multiple to mean one and the same thing.

PER indicates how much investors are willing to pay for each currency unit of a firm's earnings. It also reflects investor's confidence and sentiment about a firm's future performance and influences investment decisions. The share price and the earnings of PER are themselves influenced by accounting inherent factors and fundamental factors. Premkanth (2013) suggested that comparison of price-earnings ratio over time is meaningless unless changes in the underlying fundamental determinants of PER are taken into account.

PER is additionally utilized in valuations related to corporate exchanges. For example, the board uses it to formulate strategies in acquiring required subsidies for the organization. PER method enables speculators make forecast on what would firms' future exhibitions may resemble (Afza and Tahir, 2012). In that capacity, PER is one of the proportions used in relative valuation strategies to decide if a specific firm is exchanging higher or lower than its peers (Larsen, Fabozzi and Gowlland, 2013).

PER was found to yield highly accurate valuation performance compared to other multiples in the plantation sector of Bursa Malaysia from 2003 to 2009, when ROE is used as a control factor (Fei, 2011).

PER is utilized to make proposals to purchase, hold, or move stocks. Certain stocks with low PE ratios when contrasted with their peers are observed to be underestimated, while firms having higher PE proportions are considered to have noteworthy prospects for development (Hillier, Ross, Westerfield, Jaffe and Jordan, 2010). It shows along these lines whether a stock is less expensive or costly: less expensive stocks are the more profitable ones.

The ubiquity of PER lies in the effortlessness of its strategy as it speaks of just a proportion of a market value variable (e.g., stock cost) to a specific significant driver (e.g., profit) of a firm. Contrasted with complex valuation methods, it requires fewer presumptions. 
In spite of the effortlessness in its methodology, PER requires organized procedures and comprehension of significant drivers of products connected. Except if these two zones are appropriately tended to, the PER methodology may result to lacking valuations. In light of its popular use in most exchanges and examinations led by experts, surviving investigations on these two regions do not give sufficient experimental discoveries, particularly in creating capital markets for the Philippines.

\section{Statement of the Problem}

At present, there is a low turnout of published studies on this area, especially in developing countries such as the Philippines. To the best knowledge of the author, no study has identified and evaluated price-earnings ratio value drivers, both along macroeconomic and firm-specific levels.

\section{Objectives of the Study}

Generally, this study aims to identify significant value drivers of PER of universal banks in the Philippines on the macroeconomic and firm levels. Universal banks were chosen as sources of data because of their significant role in the Philippine economy and the banking system in general. Selection of variables was mainly taken from literatures reviewed, and grounded on theories presented in the theoretical framework.

The rest of the paper is organized in the order of literature review that defined theoretical bases of the research and review of related studies; design of conceptual framework; research method; results and analysis; and conclusion.

\section{Literature Review}

\section{Theoretical Framework}

\section{Efficient Market Hypothesis}

Price-Earnings Ratio is calculated as the ratio of share market price over earnings per share. One of the theories this research is grounded to is the efficient market hypothesis, considered to be one of the cornerstones of modern asset pricing for the past 50 years (Fakhry, 2016). One of the most important assumptions of the hypothesis is that no investor may have extraordinary returns using any information (Bayraktar, 2012). The price of securities completely reflects all the existing information in the market; therefore, no investor would obtain differentiated returns.

Efficient market hypothesis explains important characteristics of the stock market and these are (Koller, Goedhart, and Wessels, 2010):

-Share prices more or less are aligned with intrinsic value since informed investors are the market price setters and its boundaries;

-Boundaries for share prices either in the lower or upper limit of the intrinsic value becomes wider when there is uncertainty in the stock's valuation;

-When no new information about the firm has been revealed, share prices can be highly volatile but within the bounds of the limits set by informed investors;

- Deviations in price outside the boundaries set by informed investors using intrinsic valuation happen only in rare situations, such as when informed investors were outnumbered or when institutional barriers hamper selling the stocks

One of the advantages of using multiples (e.g. PER) is, it assumes the efficient market hypothesis implicitly, and expected future cash flows and discount rates that are market-estimated are indirectly utilized (Kim, 2015). Because of this advantage, estimation of future cash flows and discount rates were able to minimize substantial estimation errors, making multiples be one of the favored valuation models in practice (Kim, 2015). 


\section{Dividend Discount Model}

The dividend discount model is a valuation theory that looks into growth rate as an important determinant of stock price. This is the oldest valuation model in practice, and the underlying principle is that when investors buy stocks in publicly listings, cash flows from dividends during the holding period and anticipated price at the end of the holding period are expected (Damodaran). In its most basic form, the formula for Price at the end of the period is given in the following form (Welc, 2011):

$$
P_{t}=\frac{D_{t}(1+g)}{(r-g)}
$$

where: $\mathrm{Pt}=$ price of the stock at the end of the period

$\mathrm{Dt}=$ Dividends at the end of the period

$g=$ growth rate; and $r=$ discount rate

Penman (1997 cited in Welc, 2011) posited that substituting accrual earnings to cash flows improved accuracy of valuation, therefore, substituting dividends with earnings will change the form to:

$$
P_{t}=\frac{E_{t}(1+g)}{(r-g)}
$$

Dividing both sides of the equation by earnings at time $t(E t)$ will give PER to be equal to $[(1+g) \div(r-g)]$. This makes growth rate to be an integral component of PER.

In order to maximize shareholders' value, firms need to identify growth drivers and what makes it create value (Koller, et al., 2010). High growth and how it would be sustained is a challenge because innovations have to be introduced in product life cycles.

\section{Molodovsky Effect}

The Modolovsky Effect was introduced in 1953 by Nicholas Molodovsky in an article entitled "A Theory of Price Earnings Ratios" published in the Financial Analysts Journal (Williams Equity Research, 2015). Molodovsky discovered that P/E ratios were often much higher during depressed points of the business cycle compared to when earnings are higher during peak business cycles (Williams Equity Research, 2015).

\section{Review of Related Studies}

The study of Sehgal \& Pandey (2010) was on the use of alternative price multiples for equity valuation of 145 companies in 13 sectors listed in Bombay Stock Exchange from the period 1990 2007. Using two forecast evaluation criteria and Theil's inequality coefficient, the study showed that among three value drivers that were regressed to historical prices as independent variable, price earnings is the best price multiple in developing price forecasts in the Indian context (Sehgal \& Pandey, 2010). The study of Rostan and Rostan (2012) showed that PER is a better predictor of financial and market performance of firms compared to Customer Satisfaction index. This conclusion was made on selected five financial and seven market indicators considered as proxies for financial and market performances of eighty-five companies in the S\&P 500 index (Rostan \& Rostan, 2012).

GDP growth rate is a measure of economic growth. In a Forbes article written by Ferri (2012), the author stated that PER appears to contract when economic growth is slowing, and expands when GDP is expected to expand or grow and inflation is over 6 percent. This analysis was made on a 10-year rolling correlation of GDP growth with P/PeakE, by lagging the latter by one [1] year to allow how current valuations are impacted by GDP growth anticipations the next year.

The study of Murcia (2014) included macroeconomic variables and the stock market index PSEi as factors that drive the performance of the Philippine Stock Market, while the inclusion of company fundamentals as value drivers were identified in the study of Dawar (2012) on stock pricing of the automotive sector in India. 
Yuanlong (2012) examined a firm's forward PER relative to EPS growth rate and positive correlation between the PE ratio and the firm's short-term expected earnings growth rate was found. Markuson (2012) made a study on the valuation of a public bank using a banking institution in Spokane Washington known as Sterling Financial Corporation, and methods used were relative and discounted cash flow valuation. According to the study, $85 \%$ of equity research analysts use relative valuation, with price to book value (PBV) as the most commonly used multiple valuations for financial institutions (Markuson, 2012). Interestingly, PER or P/E multiple was not among the chosen valuation method for this bank.

A macro-economic factor involved in determining PER is inflation. Inflation is defined as a sustained increase in the general level of prices for goods and services. It is measured as an annual percentage increase (Farooq \& Ahmed, 2017). PER tends to expand when interest rates and inflation decrease while it contracts if otherwise (Clarke, 2014). Given that inflation leads to higher variability in prices, it becomes hard for economic agents to detect relevant information from prices (Hsu, Kudo, Yamada, 2013). Basu et al. (2010) showed that expected inflation information were not fully incorporated by analysts in their forecasts.

In the context of the mispricing (either undervalued or overvalued) view, PER is contrarily identified with portfolio stock returns. In particular, stocks with low PER procure higher returns than stocks with high PER, suggesting that investors could gain higher returns by putting resources into low PER portfolios. Basu (1977, cited in Thalmann, 2016) presented this recommendation and did experimental research to test the theory. The research found that low PER portfolios procure predominant hazard balanced returns while utilizing the New York Stock Exchange or NYSE mechanical firms between September 1956 to August 1971. Basu (1983, cited in Thalmann, 2016) improved his past research and found that high earning (low PER) stocks earned altogether more serious hazard balanced returns even in the wake of controlling for firm size.

A systematic literature review made by Plenborg \& Pimentel (2016) identified choice of comparable firms as among the implementation issues on the use of multiples valuation method.

Profitability is one indicator for evaluating firm performance. Profitability measures are fundamental to multiples when measuring risk and return (Pétursson, 2016). Amongst profitability indicators are: return on equity or ROE, return on asset or ROA, asset turnover (ATO) and so forth. In an examination of the association between forward PER and profitability, the study of Wu (2014) observed that there exists a Ushape relationship between forward PER and ROE. Moreover, the study shows that firms having high PER tend to have lower ROE in the following years. Similarly, the study by Premkanth (2013) on sample of 30 companies listed on the Colombo Stock Exchange over the period 2007-2011 showed that ROE impact negatively on PER, but not sufficient to explain PER. Sezgin (2010) observed unidirectional Granger's running from $R O E$ to $P E R$.

The study of Maniar (2014) revealed highest correlation to exist between price-to- book value or PBV multiple and Return on Capital Employed or ROCE, followed by ROE and PBV multiple. ROE and ROCE are measures of capital efficiency and hence could be a proxy for how two companies with same amount of net worth could be differentiated (Maniar, 2014).

The study of Deev (2011) was on common bank valuation models that included the following approaches: asset-based, market-based, income-based, and contingent claim valuation. Asset-based valuation was used to determine the liquidation value of a bank during legal proceedings, however, this approach is difficult to use when the banks widens its range of services (Deev, 2011). Market-based approach was the simplest method because of the availability of data, reports, and experts' opinions where comparison of multiples can be made, and the most sufficient multiples for valuation of banks are PER and, PBV (Deev, 2011). There are three variables that influence banks' PER: dividend payout (DPO) ratio, earnings growth rates, and cost of equity (Deev, 2011). The income-based approach looks into the present value of future economic benefits, with free cash flow on equity or FCFE to be highly valid for valuation of banks, and dividend discount model [DDM] to be another form valuation (Deev, 2011). Contingent claim valuation such as binomial and the BlackScholes-Merton models can be used for valuation of banks (Deev, 2011).

The study of Gounder \& Venkateshwarlu (2017) compared residual income model and relative valuation model as methodologies for bank valuation using 40 listed public and private banks operating in India within 
the study period of 2001 2015. The study concluded that residual income model is more appropriate in value determination for banks' shareholders' value, using correlation analysis and regression (Gounder \& Venkateshwarlu, 2017). PER is one of the tools for relative valuation model, and the researchers pointed out that one of the limitations of relative valuation is, it cannot be utilized for future oriented decisions because it is based on current market data (Gounder \& Venkateshwarlu, 2017).

The study of Forte, Gainfrante, \& Rossi (2018) looked into the suitability of stock multiples in valuation of banks in the US and Europe. The study showed that multiples are less accurate for small commercial banks compared to large ones, and for investment banks compared to retail banks. Moreover, PER loses its predictive ability when compared with historical multiples (Forte, et al., 2017). The research findings also concluded that multiples for US banks are more accurate than that of multiples for European banks.

The study of Shaalan (2018) proposed a model for commercial bank valuation using data of listed commercial banks in Bahrain Stock Exchange. The study resulted to identifying independent variables that influence the intrinsic value of commercial banks and these were operational efficiency, bank adequacy, size of assets, and ROE (Shaalan, 2018).

The study of Jitmaneeroj (2015) looked into the relationship between PER and dividend policy. Using fixed effects panel regression method for data comprised of industries in the United States from 1998 to 2014, the study showed that when ROE is greater than the required rate of return, PER and dividend payout ratio are negatively correlated while displaying positive convexity (Jitmaneeroj, 2015). The study recommended that the convex relationship between PER and dividend payout ratio should be considered to avoid premature conclusion that PER is positively related to dividend payout ratio (Jitmaneeroj, 2015).

A study conducted on 47 non-financial firms listed at the Nigerian Stock Exchange used quantile and pooled regression models, and found that dividend pay-out ratio is statistically significant to influence P/E ratio at the 25th, 50th and 75th percentiles. At the 25th percentile, dividend per share has significant but negative impacts on PER while dividend pay-out ratio and total dividend paid has positive significant impacts on PER. At the 50th percentile, dividend pay-out ratio has significant and positive impacts on PER while dividend per share has significant but negative influence on PER. At the 75th percentile, dividend pay-out ratio and average share price has positive and significant effects on P/E ratio (Emudainohwo, 2017).

Isidro \& Grilo (2014) looked into value drivers of banks in the Eurozone using accounting-based valuation models, and the study identified salient characteristics of the model which are: development of correlation between free cash flows from fees on income and bank value based on lending and borrowing activities; and proprietary investment and trading activities as value drivers. It was found that proprietary investment and trading of financial assets are significant income-generating sources of banks that are diversified (Isidro \& Grilo, 2014).

\section{Synthesis of the Literatures Reviewed}

It is for this reason that the researcher felt the need to conduct a thorough study on Price-Earnings Multiple as an investment assessment tool. Literatures reveal that PER has been useful in analyzing stock performance, and with seemingly similar conclusions. For example, the study of Clarke (2014) concluded that P/E multiple tend to expand when the interest rates and inflation decrease, and contracts if otherwise. Moreover, multiples that are composite equity-based are found to provide more accurate valuations compared to optimal equity-based single-factor multiples (Nel \& Le Roux, 2017). Most of the studies are on selected firms in stock exchanges and appears to be in varied industries. No notable studies that explored PER as valuation tool for firms of specific industries were found, and the basis of choosing the banking industry was rooted on Plenborg \& Pimentel (2016). Moreover, the studies of Sehgal \& Pandev (2010), Rostan \& Rostan (2012), and Homes \& Chira (2014), confirmed the superiority of PER as valuation tool. Similar local studies (Sehgal \& Pandey, 2010; Jitmareenoi, 2015; Emudainohwo, 2017; Gounder \& Venkateshwarlu, 2017; Shaalan, 2018) focused on PER drivers using a combination of various industries but none has been found for specific industries. The choice of the variables interest rates and inflation were derived from the studies of Clarke (2014), Farooq \& Ahmed (2017), and Hsu, et al., (2013), while ROE, ROA, and other profitability measures were taken from the studies of Premkath (2013), and Sezgin (2012). The 
inclusion of dividend payout ratio as one of the variables was taken from Emudainohwo, (2017). The choice of ROE growth rate to be included in the model was derived from the study of Pettersen (2011). The influence of GDP growth rate was taken from Ferri (2012) while earnings growth rate as one of the variables was from Yuanlong (2012). The choice of PBV was from the study of Markusson (2012) on financial institutions as the most commonly used multiple valuations, as well as that of Maniar (2014) on the correlation of PBV and ROE. The combination of companies' financial fundamentals and macroeconomic variables as possible drivers of PER was derived from the studies of Murcia (2014), and Dawar (2012).

\section{Conceptual Framework}

Figure 1 shows the conceptual framework followed in this study. It shows the possible determinants used as independent variables that drive PER. Following the input-process-output model, the value drivers are the inputs, then processed using multiple regression to produce a model for price-earnings ratio for universal banks in the Philippines.

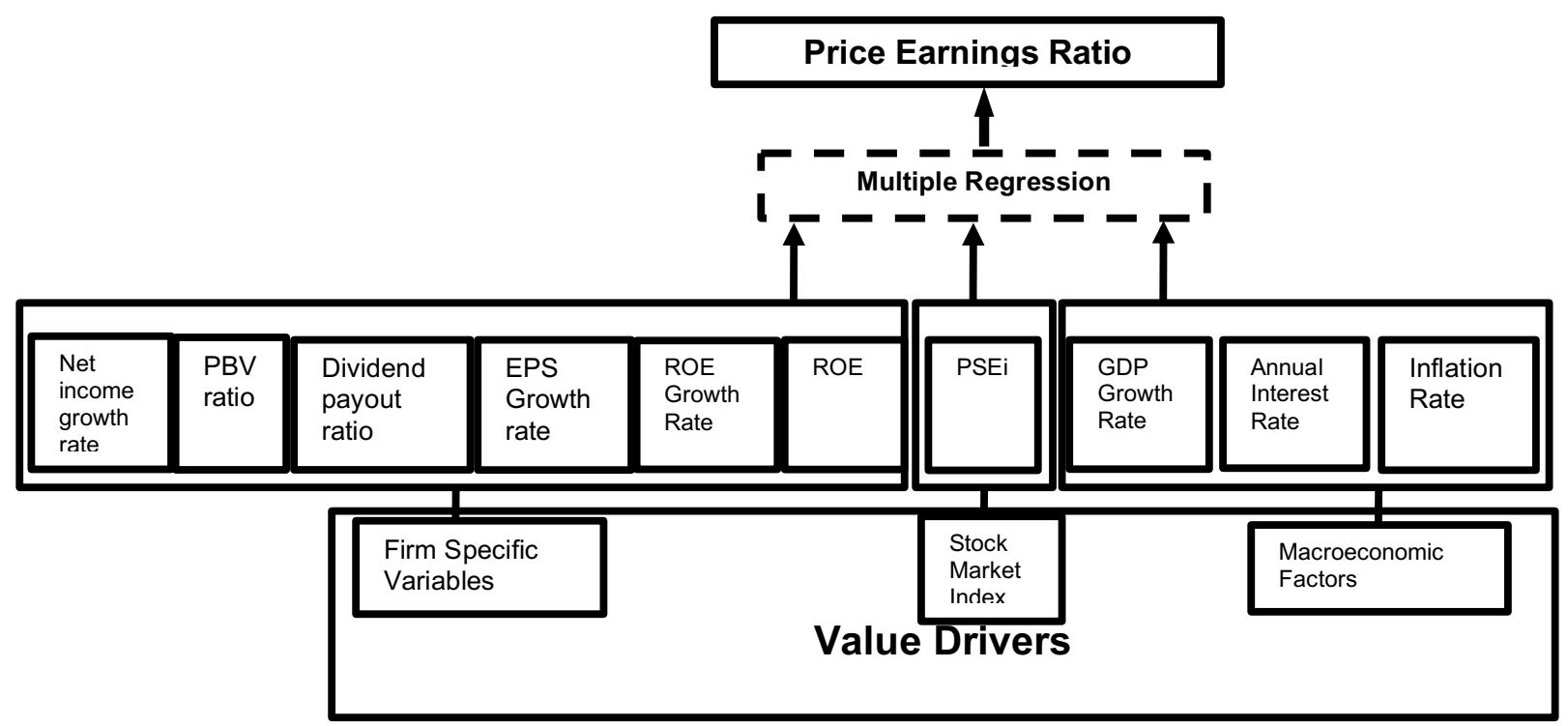

Figure 1: Conceptual Framework

\section{Research and Methodology}

\section{Research Method}

Establishing the theoretical foundation of this study is based on the development of the valuation model. Multiple regression uses the following form:

$$
\text { Yit }=\alpha i+\beta 1 X i 1+\beta 2 X i 2+\beta 3 X i 3+\ldots . . \beta i t X i t
$$

Where: yij is the outcome variable (or dependent variable) for a particular ij case

$\beta n$ are the regression coefficients

Xit are regression predictors or independent variables

ai is the intercept or constant.

\section{Subjects and Study Sites}


Bangko Sentral ng Pilipinas [BSP] regulates forty-four (44) banks in the country, twenty-one [21] of which are universal banks. Among these, ten [10] universal banks listed in the Philippine Stock Exchange were utilized because these banks account for $93 \%$ in terms of capitalization of banks listed in PSE. Universal banks in the Philippines have been resilient in spite of global challenges that affected financial markets in the past such as the fall of the Lehman Brothers, the Great Tsunami in Japan, and political unrest in the Middle East (Bangko Sentral ng Pilipinas, 2011).

The period for this study was from 2010 to 2017. All data are secondary in nature and were collected from the financial statements of the selected companies. Macroeconomic variables were also considered in this study as these impact banks' performance. The names of the banks were not indicated in this study for confidentiality. Instead, the banks' identities were labeled as bank 1, bank 2.,,, and so forth.

\section{Research Instruments/Data Measure}

As mentioned, secondary data was used in this study. The data on firm specific variables were generated from the Annual Reports of the selected universal banks. The PSE website was the source of information for market price per share and earnings per share to determine the P/E ratio. Moreover, the BSP was the basis in getting the complete list of the banks in the country, particularly the roster of the universal banks. For macroeconomic factors, data was collected from the Philippine Statistics Authority [PSA] database - a compilation of the measures of gross domestic product, inflation rate, and annual interest rate.

\section{Description of the Variables Used}

The dependent variable is Price Earnings Ratio or PER and is measured as the ratio of the share's current market price over earnings per share.

The independent variables are:

Net Income Growth Rate: This is the percentage change in net income and is calculated as the ratio of the difference between previous period and current period net income over the previous period's net income

Price to Book Value [PBV] Ratio: This is the ratio of the share's current market price over the book value per share.

Dividend Payout (DPO) Ratio: This is the ratio of dividends paid over net income.

EPS Growth Rate: This is the percentage change in earnings per share and is calculated as the ratio of the difference between previous period and current period earnings per share over the previous period's earnings per share.

Return on Equity $(R O E)$ : This is a portion of net income relative to shareholders' equity

$R O E$ growth rate: This is the percentage change in earnings per share and is calculated as the ratio of the difference between previous period and current period earnings per share over the previous period's earnings per share.

PSEi: This is the index provided by the Philippine Stocks Exchange on a yearly basis.

GDP Growth Rate: This is the percentage change in gross domestic product or GDP and is calculated as the ratio of the difference between previous period and current period gross domestic product over the previous period's gross domestic product. Gross Domestic Product was taken from the Philippine Statistics Authority.

Inflation rate and Interest Rate: This is provided by the BSP and PSA.

\section{Statistical Treatment of Data}

Descriptive Statistics. The characterization of each variable was determined using mean and standard deviation. In addition, correlation analysis of companies' PER and value drivers, Pearson R correlation was calculated to find out the inter-relationship between variables such as macroeconomic factors, stock market indices, and firm specific variables. 
Multiple Regression. Considering the individuals (banks) and time specifications (eight-year period from 2010-2017), a multiple regression analysis was used in determining the impact of the independent variables, and develop a relevant model utilizing the identified value drivers. Before conducting the regression analysis, various tests were conducted to satisfy the assumptions under this approach. These assumptions include normality of distribution, linearity, existence of possible outliers. Goodness-of-fit Kolmogorov-Smirnov test was performed to inspect whether samples obey the normal distribution and the uniform distribution of the P/E ratio.

A histogram was shown to present the normal distribution of PER. Variance Inflation Factor was utilized to confirm issues with multicollinearity. Mahalanobis distance test was executed to determine outliers among the samples.

\section{Results and Analysis}

\section{Descriptive Statistics}

Table 1 shows the descriptive statistics of the dependent and independent variables. The mean PER is 11.737 and is satisfactory since the data follows a normal distribution (based on the results of the one-sample Kolmogorov-Smirnoff test presented in Table 3).

The standard deviation is quite high, indicating some levels of variability in the data. This means that banks' PER are independent of each other's performance. Other variables have fairly less variability exhibited.

Table 1: Descriptive Statistics

\begin{tabular}{|lcccccc|}
\hline & $\mathrm{N}$ & Minimum & Maximum & Mean & Std. Deviation & Variance \\
PER & 80 & 0.5822 & 25.5452 & 11.7374 & 4.7095 & 22.1795 \\
ROE & 80 & 0.0555 & 0.2818 & 0.1211 & 0.0390 & 0.0015 \\
ROE Growth Rate & 80 & $(0.5095)$ & 1.4293 & 0.0358 & 0.2795 & 0.0781 \\
EPS Growth Rate & 80 & $(0.9237)$ & 1.5938 & 0.0871 & 0.3308 & 0.1094 \\
DPO Ratio & 80 & 0 & 1.0651 & 0.2587 & 0.2295 & 0.0527 \\
PBV Ratio & 80 & 0.5486 & 3.7640 & 1.4824 & 0.6877 & 0.4729 \\
Net Income Growth & 80 & $(0.3253)$ & 1.9126 & 0.1757 & 0.3186 & 0.1015 \\
Rate & & & & & & $1,220.1625$ \\
PSE index & 80 & $4,055.5400$ & $7,979.8300$ & $6,504.2238$ & $1,488,796$ \\
Inflation Rate & 80 & 0.7000 & 4.7000 & 2.8500 & 1.2376 & 1.5316 \\
GDP Growth Rate & 80 & 3.6600 & 7.6320 & 6.3516 & 1.1258 & 1.2673 \\
Interest Rate & 80 & 2.3000 & 6.2000 & 3.5990 & 1.1194 & 1.2531 \\
\hline
\end{tabular}

\section{Correlation}

Table 2 shows the correlation coefficients of each variable relative to other variables using Pearson Correlation. Most of the variables are weakly correlated except for PBV ratio and PER with a value of 0.6. This is expected since the same market share price is used. Similarly, ROE growth rate and EPS growth rate are strongly positively correlated at 0.7 because earnings per share are related to net income. Net income growth rate is positively correlated with ROE growth rate and EPS growth as these growth rates refer to the same net income. Even with several levels of positive correlation, the following assumption tests to proceed with multiple regression were still met. Linearity is observed among pairs of variables with asterisk $\left(^{*}\right)$

Table 2: Correlation Matrix 
Dayag \& Trinidad / International Journal of Research in Business and Social Science,

Vol 8 No 4, 2019 ISSN: 2147-4486

\begin{tabular}{|c|c|c|c|c|c|c|c|c|c|c|c|}
\hline & PER & ROE & $\begin{array}{l}\text { ROE } \\
\text { Growth } \\
\text { Rate }\end{array}$ & $\begin{array}{l}\text { EPS } \\
\text { Growth } \\
\text { Rate }\end{array}$ & $\begin{array}{l}\text { DPO } \\
\text { ratio }\end{array}$ & $\begin{array}{l}\text { PBV } \\
\text { ratio }\end{array}$ & $\begin{array}{l}\text { Net } \\
\text { Income } \\
\text { Growth } \\
\text { Rate }\end{array}$ & $\begin{array}{l}\text { PSEi } \\
\text { index }\end{array}$ & $\begin{array}{l}\text { Inflation } \\
\text { Rate }\end{array}$ & $\begin{array}{l}\text { GDP } \\
\text { Growth } \\
\text { Rate }\end{array}$ & $\begin{array}{l}\text { Interest } \\
\text { Rate }\end{array}$ \\
\hline PER & 1 & & & & & & & & & & \\
\hline ROE & $(0.3)^{\star \star}$ & 1.0 & & & & & & & & & \\
\hline $\begin{array}{l}\text { ROE } \\
\text { Growth } \\
\text { Rate }\end{array}$ & $(0.3)^{\star}$ & $0.4^{* *}$ & 1.0 & & & & & & & & \\
\hline $\begin{array}{l}\text { EPS } \\
\text { Growth } \\
\text { Rate }\end{array}$ & $(0.2)$ & $0.4^{\star \star}$ & $0.7^{\star \star}$ & 1.0 & & & & & & & \\
\hline $\begin{array}{l}\text { DPO } \\
\text { Ratio }\end{array}$ & $0.3^{\star *}$ & 0.2 & 0.0 & $(0.1)$ & 1.0 & & & & & & \\
\hline $\begin{array}{l}\text { PBV } \\
\text { Ratio }\end{array}$ & $0.6^{\star \star}$ & 0.1 & $(0.1)$ & $(0.0)$ & $0.4^{\star *}$ & 1.0 & & & & & \\
\hline $\begin{array}{l}\text { Net } \\
\text { Income } \\
\text { Growth } \\
\text { Rate }\end{array}$ & $(0.2)$ & $0.4^{\star \star}$ & $0.7^{\star \star}$ & $0.8^{\star *}$ & $(0.1)$ & $(0.1)$ & 1.0 & & & & \\
\hline $\begin{array}{l}\text { PSE } \\
\text { index }\end{array}$ & $0.3^{\star *}$ & $(0.4)^{\star \star}$ & $(0.3)^{\star *}$ & $(0.2)$ & $(0.0)$ & $(0.1)$ & $(0.3)^{* *}$ & 1.0 & & & \\
\hline $\begin{array}{l}\text { Inflation } \\
\text { Rate }\end{array}$ & $(0.1)$ & 0.4 & 0.1 & 0.0 & 0.0 & 0.2 & 0.1 & $(0.6)^{\star \star}$ & 1.0 & & \\
\hline $\begin{array}{l}\text { GDP } \\
\text { Growth } \\
\text { Rate } \\
\end{array}$ & 0.1 & $(0.1)$ & 0.2 & $0.3^{* *}$ & 0.0 & 0.0 & 0.2 & 0.2 & $(0.4)^{\star \star}$ & 1.0 & \\
\hline $\begin{array}{l}\text { Interest } \\
\text { Rate }\end{array}$ & 0.0 & $(0.2)$ & 0.0 & $(0.0)$ & 0.0 & $(0.1)$ & (0.1) & $0.3^{* *}$ & (0.9) & 0.2 & 1.0 \\
\hline
\end{tabular}

Note: Correlations with ${ }^{*}$ or ${ }^{* *}$ are significant at $p<0.05$

\section{Assumptions Test}

Table 3 shows the normality of distribution that was determined by testing the null hypothesis that the data is normally distributed. If the p-value using Kolmogorov-Smirnov test is less than 0.05 , then the null hypothesis is rejected. Our data showed that $p$-value is $0.200(p>0.05)$ therefore we accept the null hypothesis that the dependent variable is normally distributed. Figure 2 shows the histogram chart depicting the distribution of the data and confirming normality of distribution.

Table 3: Kolmogorov-Smirnov Test

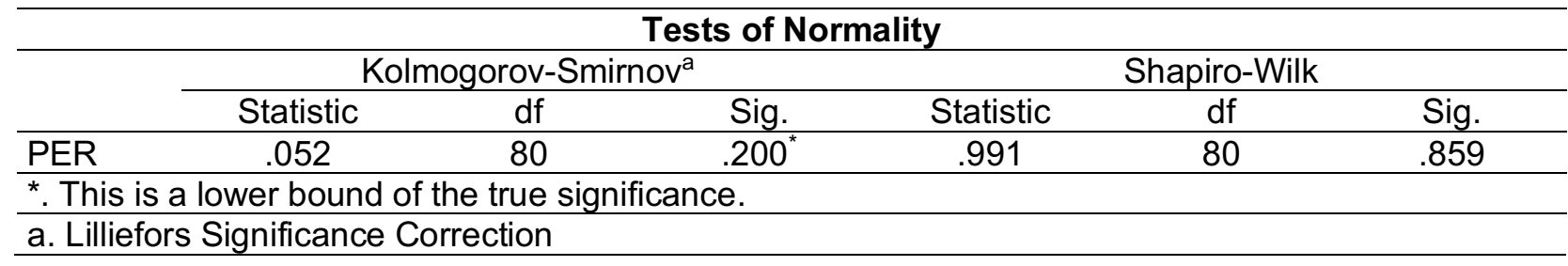

Figure 2: Histogram Chart

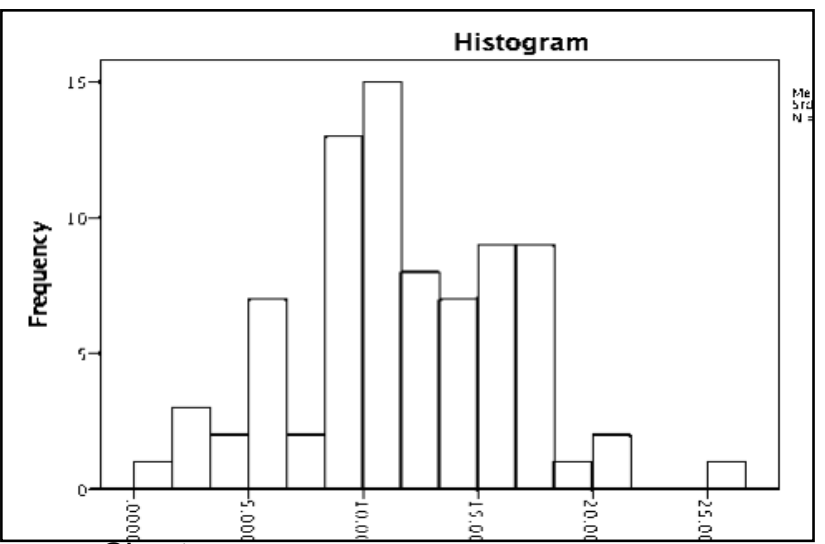

\section{Test for Multicollinearity}

Table 4 shows variables with VIF values less than 10 that are considered acceptable for absence of multicollinearity. Except for inflation rate, the rest of the variables were considered in the regression 
analysis. Since inflation rate's VIF is 10.3, this researcher decided to still include this variable since it is a little close to 10, and several literatures such as the studies of Clarke (2014), Farooq \& Ahmed (2017), and Hsu, Kudo and Yamada (2013), demonstrated the importance of inflation rate as one of the value drivers of PER.

Table 4: Variance Inflation Factor (VIF)

\begin{tabular}{|c|c|c|c|c|c|c|c|}
\hline & & Coe & icients ${ }^{a}$ & & & & \\
\hline & $\begin{array}{r}\text { Unstar } \\
\mathrm{C}\end{array}$ & $\begin{array}{l}\text { dardized } \\
\text { eff. }\end{array}$ & $\begin{array}{l}\text { Standardized } \\
\text { Coeff }\end{array}$ & & & Collinearit & atistics \\
\hline Model & B & Std. Error & Beta & $\mathrm{t}$ & Sig. & Tolerance & VIF \\
\hline $1 \quad$ (Constant) & 1.679 & 8.397 & & .200 & .842 & & \\
\hline ROE & -40.018 & 11.148 & -.334 & -3.590 & .001 & .612 & 1.634 \\
\hline ROE Growth Rate & -1.393 & 2.297 & -.083 & -.606 & .546 & .280 & 3.570 \\
\hline EPS Growth Rate & -1.322 & 2.417 & -.094 & -.547 & .586 & .181 & 5.510 \\
\hline DPO Ratio & 1.959 & 2.002 & .088 & .978 & .331 & .650 & 1.539 \\
\hline PBV Ratio & 4.098 & .604 & .601 & 6.786 & .000 & .676 & 1.479 \\
\hline Net Income Growth Rate & 2.427 & 2.471 & .166 & .982 & .329 & .187 & 5.355 \\
\hline PSE index & .001 & .000 & .336 & 2.854 & .006 & .382 & 2.615 \\
\hline Inflation Rate & .035 & .892 & .009 & .040 & .968 & .095 & 10.3 \\
\hline GDP Growth Rate & -.057 & .383 & -.014 & -.148 & .883 & .633 & 1.581 \\
\hline $\begin{array}{l}\text { Interest Rate } \\
\text { a. Dependent Variable: PER }\end{array}$ & -.092 & .755 & -.022 & -.122 & .904 & 162 & 6.189 \\
\hline
\end{tabular}

\section{Mahalanobis Distance Test for Outliers}

One outlier was found in the Mahalonobis distance test: Bank 4 for 2010 with Prob_MAH of 0.0003 . Values of Prob_MAH that are less than 0.001 are advised to be removed from the data set prior to running the inferential analysis (Statistics Solutions). This was removed in the final data set for the multiple regression analysis.

\section{Multiple Regression Results}

Table 5 shows the multiple regression model summary using Statistical Package for the Social Sciences (SPSS) version 23 that was run to predict PER and as shown, the multiple correlation coefficient $R$ is 0.898 or $89.8 \%$. This result indicates a good level of prediction. The coefficient of determination R2 explains the proportion of variance in the dependent variable PER that can be explained by the independent variables. The value is 0.637 or $63.7 \%$, which means that the independent variables explain $63.7 \%$ of the variability in the dependent variable PER.

Table 5: Model Summary

\begin{tabular}{|lcccc|}
\hline \multicolumn{4}{|c|}{ Model Summary $^{\mathbf{b}}$} \\
\hline & $\mathrm{M}$ & $\mathrm{R}$ Square & Adjusted R Square & Std. Error of the Estimate \\
1 & $.898^{\mathrm{a}}$ & .637 & .583 & 2.99051994 \\
\hline $\begin{array}{l}\text { a. Predictors: (Constant), Interest Rate, ROE Growth Rate, DPO Ratio, GDP Growth Rate, PSE index, } \\
\text { PBV Ratio, ROE, Net Income Growth Rate, EPS Growth Rate }\end{array}$ \\
b. Dependent Variable: PER
\end{tabular}

Table 6 shows the ANOVA summary result and describes the overall fit of the regression model, and at $F(10,68)=11.916, p(0.000)$ is less than 0.05 which means that the regression model is a good fit for the data. 
Dayag \& Trinidad / International Journal of Research in Business and Social Science,

Vol 8 No 4, 2019 ISSN: 2147-4486

Table 6: Analysis of Variance Summary

\begin{tabular}{|c|c|c|c|c|c|}
\hline \multicolumn{6}{|c|}{ ANOVA $^{a}$} \\
\hline Model & Sum of Squares & df & Mean Square & $\mathrm{F}$ & Sig. \\
\hline 1 Regression & 1065.666 & 10 & 106.567 & 11.916 & $.000^{\mathrm{b}}$ \\
\hline Residual & 608.138 & 68 & 8.943 & & \\
\hline Total & 1673.805 & 78 & & & \\
\hline
\end{tabular}

Table 7 shows the coefficients of regression with ROE $(p=0.000), P / B$ ratio $(p=0.000)$, and PSEindex $(p=0.009)$ to be the variables that are significant in the regression equation. ROE significantly reduces PER while PBV ratio, net income growth rate, and PSE index significantly increase PER. The rest of the variables' coefficients do not have statistical significance. Therefore, to predict PER at time $t$, the regression equation is:

PERt $=1.099-45.086^{\star}$ ROE $-1.108^{*}$ ROE Growth Rate $-1.34^{*}$ EPS Growth Rate $+3.120^{*}$ DPO Ratio + 4.146*PBV Ratio $+4.184^{*}$ Net Income Growth Rate $+0.001^{*}$ PSEindex $+0.179^{*}$ Inflation Rate $+0.026^{*}$ GDP Growth Rate $+0.024^{*}$ Interest Rate

Variables that resulted to statistical insignificance but nevertheless contributed to the regression model are DPO ratio, net income growth rate, ROE growth rate and EPS growth rate.

Table 7: Coefficients of Regression

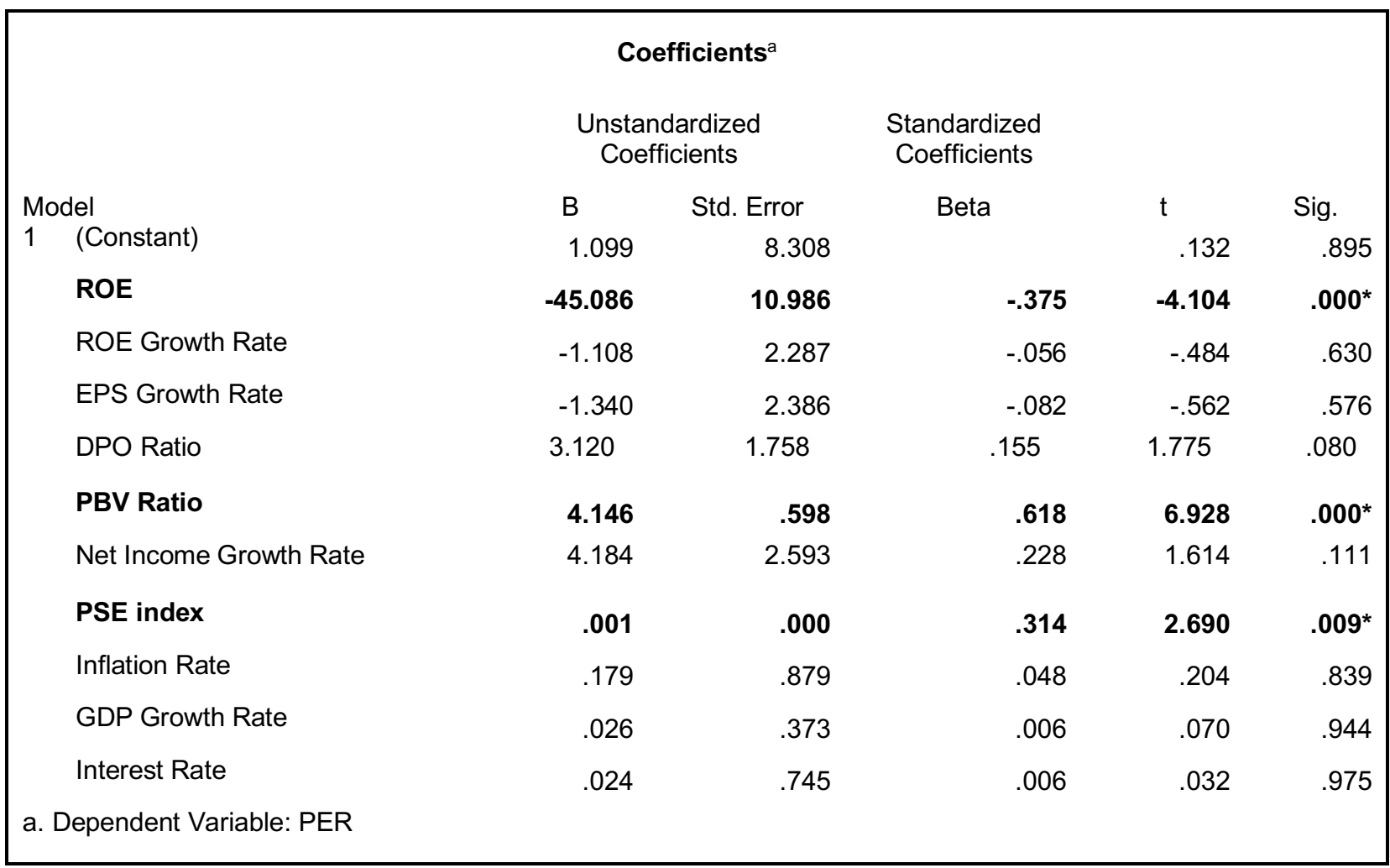

\section{Discussion}

Significant variables are found to be those with $p$-values that are less than the significance level of 0.05 and these are: $R O E$ with $p$-value $=0.000, P / B$ ratio with $p$-value $=0.000$, and PSEi with $p$-value $=0.009$. 
The coefficient of ROE is -45.086 , which means that as ROE increases, P/E ratio declines by a factor of 45.086. ROE negatively impacts PER, and this is similar to the findings of Premkath (2013) \& Sezgin (2012). The inclusion of $\mathrm{P} / \mathrm{B}$ ratio as a significant value driver is concluded to be an added feature of this regression model for P/E ratio of universal banks, which is similar to the study of Maniar (2014). As expected, PSE index influences P/E ratio because stock markets dictate price of stocks. ROE negatively impacts P/E ratio by a large amount, and this large and negative coefficient is consistent with the findings of Premkanth (2013). However, in previous studies, ROE is not statistically significant.

The inverse relationship between ROE and P/E ratio is explained by the reversal effect, or the Molodovsky effect, based on literature. Assuming that the variables share price, outstanding number of shares, and shareholders equity are kept constant, while net income is varied, Table 8 illustrates scenarios showing the impact of increase or decrease on net income on ROE and P/E ratio. When banks' ROE increase, P/E may decline assuming market price keeps minimum volatility or are kept at some steady trend. On the other hand, when banks' ROE decrease, $\mathrm{P} / \mathrm{E}$ increases. It implies that an increase in ROE is not favorable because P/E ratio declines. It means that when $\mathrm{ROE}$ increases, the price that investors are willing to pay per unit of share is reduced.

Table 8: Illustration of Reversal Effect

\begin{tabular}{|lrrr|}
\hline Given: & Year 2018 & Year 2019 & \\
Market Price & 100 & 100 & \\
Equity & $10,000,000.00$ & $10,000,000.00$ & \\
Shares outstanding & $100,000.00$ & $100,000.00$ & \\
& & & \\
Scenario 1: Net Income decreases & Year 2018 & Year 2019 & \\
Net Income & $1,000,000.00$ & $800,000.00$ & \\
EPS (Net income / shares outstanding) & 10.00 & 8.00 & \\
ROE (Net income / equity) & $\mathbf{1 0 \%}$ & $\mathbf{8 \%}$ & decrease \\
PER (Market price / EPS) & $\mathbf{1 0 . 0 0}$ & $\mathbf{1 2 . 5 0}$ & increase \\
& & & \\
Scenario 2: Net Income increases & Year 2018 & Year 2019 & \\
Net Income & $1,000,000.00$ & $1,200,000.00$ & \\
EPS (Net income / shares outstanding) & 10.00 & 12.00 & \\
ROE (Net income / equity) & $\mathbf{1 0} \%$ & $\mathbf{1 2} \%$ & increase \\
PER (Market price / EPS) & $\mathbf{1 0 . 0 0}$ & $\mathbf{8 . 3 3}$ & decrease \\
\hline
\end{tabular}

Source: Author's own analysis

\section{Conclusion}

The study confirmed that value drivers depend on short-term and long-term performance. Further, this study confirmed other findings that macroeconomic variables do not significantly impact PER and for future researches, it is recommended that other macroeconomic variables with statistical significance to PER be discovered. Although the model has a good coefficient of determination, finance professionals and researchers can further improve this model by introducing new macroeconomic variables and company fundamentals (combining both financial and non-financial metrics), of similar industries, or even other relevant industries.

In addition, this study yielded the same results as other studies that ROE negatively impacts PER and is one of the major implications of this study. The inverse relationship between ROE and PER is explained by the reversal effect. An increasing ROE is a strong indicator of efficient management of equity since higher return means every unit of equity is generating earnings, and this would appear to be favorable to investors. On the other hand, as implied by the results of this paper, rising ROE may signal decline in P/E ratio, which in effect, reflects how investors reduce the price they are willing to pay for each share of the bank's stocks. 
From this perspective, rising ROE may not be that attractive to investors. Managers may interpret increasing ROE as a reflection of how well the business was managed, but in the viewpoint of investors, this may not be the case. On this context, there are some recommended measures that the banks can take. First, when ROE is on an increasing trend, banks may reduce the number of shares outstanding so that EPS will decline, and $P / E$ ratio will rise, assuming that market price of stock fluctuates very little. Second, when ROE increases, the bank may introduce measures that will increase their value in the market. For example, the bank may intensify campaigns on corporate social responsibility, sustainability, and good governance; reduced interest rates on loan products; and increase interest rates on savings.

Emerging market valuations are complex and applicability of valuations depend on information available. There is a need to create some consistent set of macroeconomic assumptions that depend on the type of industry. A distinct characteristic that differentiates emerging markets and developed markets is, the former has higher levels of risk. Universal banks are complex to value because these entities engage in wide range of activities. These banks have many revenue generating resources in the form of interest income, and this would ultimate affect company fundamentals. The diversity and cyclicality of universal banks makes valuation a sensitive undertaking. The use of PER multiples can also demonstrate flaws, and the development of a carefully designed PER model can assist in providing insights about the firm and its peers. The value drivers identified using multiple regression are data and period dependent, and results may change from time to time. Universal banks in other emerging economies may have different sets of value drivers, and this study can help future researchers form groundwork for their own similar researches.

\section{References}

Afza, T., \& Tahir, S. (2012). Determinants of price-earnings ratio: The case of chemical sector of Pakistan. International Journal of Academic Research in Business and Social Sciences, Vol. 2 No.8, 331343.

Bangko Sentral ng Pilipinas. (2011). Philippine Banking System. Office of Supervisory Policy Development, Supervision, and Examination Sector

Basu, S., Markov, S., \& Shivakumar, L. (2010). Inflation, earnings forecasts, and post-earnings announcement drift. Rev. Accounting Stud., Vol. 15 No. 2, 403-440.

Bayraktar, A. (2012). Etkin piyasalar hipotezi, T. C. Aksaray Üniversitesi I.I.B.F. Dergisi, Vol. 3 No. 1, 37-46.

Clarke, K. (2014, May). Are Stocks Overpriced? A Smart Bull and a Smart Bear Answer the Big Question. CNN Money.com.

Damodaran, A. (2006). Damodaran on Valuation (2nd Edition ed.). New York: John Wiley \& Sons Inc.

Damodaran, A. (nd). Damodaran on Valuation. O'Reilly Safari. Retrieved from: $<$ https://www.oreilly.com/library/view/damodaran-onvaluation/9780471751212/9780471751212_dividend_discount_models.html

Dawar, V. (2012). Determinants of share prices in the Indian Auto Industry. International Journal of Computing and Business Research. Retrieved from: <http://researchmanuscripts.com/september2012/2.pdf>

Deev, O. (2011). Methods of bank valuation: a critical overview. Financial Assets and Investing. No. 3/2011, 33-44.

Emudainohwo, O. B. (2016). Firm Size and Firms' Performance: Evidence from non-Financial Service Industries in Nigeria. Ilorin Jounal of Management Science, Vol. 3 No. 1, 1-17

Emudainohwo, O. B. (2017). Determinants of Price-Earnings Ratio: Nigerian Experience (Quantile Regression). International Journal of Economics, Business and Management Research, Vol. 1 No. 5

Fakhry, B. (2016). A Literature Review of the Efficient Market Hypothesis. Turkish Economic Review, 3(3), 431-442

Farooq, O., \& Ahmed, N. (2017). Does inflation affect sensitivity of investment to stock prices? Evidence from emerging markets. Finance Research Letters, Vol. 25 No. 2018, 160-164 
Dayag \& Trinidad / International Journal of Research in Business and Social Science,

Vol 8 No 4, 2019 ISSN: 2147-4486

Ferri, R. (2012). A second look at P/E ratios (Part II). Forbes. Retrieved from: $<$ https://www.forbes.com/sites/rickferri/2012/10/25/a-second-look-at-pe-ratios-partii/\#f05eea08027d>

Fei, G. (2011). Equity valuation using multiples: an empirical study on plantation sector. Thesis. University of Gothenburg.

Forte, G., Gianfrate, G., and Rossi, E. (2018). Does relative valuation work for banks? Global Finance Journal, 1-41.

Gounder, C., and Venkateshwarlu, M. (2017). Bank valuation models - a comparative analysis. Accounting and Finance Research, Vol. 6 No. 3, 116-134

Houmes, R., and Chira, I. (2015). The effect of ownership structure on the price earnings ratio - returns anomaly. International Review of Financial Analysis, Vol. 37, 140-147

Hillier, D., Ross, S. A., Westerfield, R. W., Jaffe, J. F., \& Jordan, B. D. (2010). Corporate Finance. London: McGraw-Hill Higher Education.

Hsu, J. C., Kudoh, H., \& Yamada, T. (2013). When sell-side analysts meet high-volatility stocks: an alternative explanation for the low-volatility puzzle. J. Invest. Manage, Vol. 11 No. 2, 28-46

International Trade Administration. (2018). Philippines - Banking Systems. Retrieved from: <https://www.export.gov/article?id=Philippines-Banking-Systems>

Isidro, H., and Grilo, D. (2012). Value-driving activities in Euro-Zone Banks. European Accounting Review, Vol. 21 No. 2, 297-341, doi: 10.1080/09638180.2011.585790

Jitmaneeroj, B. (2017). The impact of dividend policy on price-earnings ratio: the role of conditional and nonlinear relationship. Review of Accounting and Finance Vol 16 No. 1, 125-140. Retrieved from: <https:doi.org/10.1108/RAF-06-2015-0092>

Kim, J. (2015). Improving practices of price and earnings estimations. Thesis. University of Edinburgh, 1-173

Koller, T., Goedhart, M., and Wessels, D. (2010). Valuation: Measuring and Managing the Value of Companies. New Jersey: John Wiley \& Sons Inc.

Larsen, G. A., Fabozzi, F. J., \& Gowlland, C. (2013). Relative Valuation Methods from Equity Analysis. Encyclopedia of Financial Models, 33-46

Maniar, B. (2014). Factors Influencing Pricing Multiples in India. The IUP Journal of Applied Finance, Vol. 20 No. $1,23-33$

Markusson, L. (2012). Public bank valuation. Business, Accounting \& Economics Undergraduate Theses 2. Retrieved from: <https://scholars.carroll.edu/business_theses/2>

Murcia, J. (2014). Macroeconomic estimation of selected Philippine Stock Market Indices. Southeast Asian Interdisciplinary Research Journal, Vol. 2, 21-30

Nel, S., and Le Roux, N. (2017). The valuation performance of mathematically-optimized, equity-based composite multiples. Journal of Economics, Finance, and Administrative Science, Vol. 22 No. 43, 224-250

Pandey, A. (2015). Earnings per share or book value: superior value driver in equity valuations. IIMS Journal of Management Science, Vol. 6 No. 1, 1-8

Pétursson, E. (2016). Relative valuation - Accuracy of Corporate Valuation Using Multiples. Lund University , School of Economics and Management. Lund University Publications Student Papers.

Plenborg, T., and Pimentel, R. (2016). Best practices in applying multiples for valuation purposes. The Journal of Private Equity

Premkanth, P. (2013). Determinants of Price Earning Multiple in Sri Lanka Listed Companies. European Journal of Business and Innovation Research, Vol. 1 No. 2, 44-56

Rostan, P., and Rostan, A. (2012). Assessing the predictive power of customer satisfaction for financial and market performance: Price-to-earnings ratio is a better predictor overall. International Review of Management and Marketing, Vol. 2 No. 1, 59-74

Segal, S., and Pandey, A. (2010). Equity valuation using price multiples: a comparative study for BRICKS. Asian Journal of Finance \& Accounting, Vol. 2 No. 1, 68-91 
Dayag \& Trinidad / International Journal of Research in Business and Social Science,

Vol 8 No 4, 2019 ISSN: 2147-4486

Sezgin, F. H. (2010). An empirical investigation of the relationship among P/E ratio, stock returns and dividend yields for Instanbul Stock Exchange. International Journal of Economic and Finanace Studies, 2(1), 15-23

Schildbach, J. (2012). Universal banks: optimal for clients and financial stability. Deutsche Bank Research. Retrieved from: <https://www.dbresearch.com/PROD/RPS_ENPROD/PROD0000000000455298/Universal_banks\%3A_Optimal_for_clients_and_financial.PD $\mathrm{F}>$

Shaalan, T. (2018). Proposed model for forecasting intrinsic value of commercial banks listed on the Bahrain Stock Exchange. Accounting and Finance Research, Vol. 7 No. 4, 91 97

Statistics Solutions. Identifying multivariate outliers in SPSS. Retrieved from: <https://www.statisticssolutions.com/identifying-multivariate-outliers-in-spss/>

Tabara, N., and Vasiliu, A. (2011). Antoine-Laurent de Lavoisier: a precursor of national accounting. EuroEconomica, $30(5) . \quad$ Retrieved from: <http://journals.univdanubius.ro/index.php/euroeconomica/article/view/1145/960>

Thalmann, G.-L. (2016). The Performance of SPI Stocks in Relation to their P/E Ratios. Zurich University of Applied Sciences, 1-45

Welc, J. (2011). Do fundamentally-adjusted valuation multiples improve valuation accuracy? The case of the Polish Stock Market. Accounting and Taxation, 3(1), 55-70. Wu, W. (2014). The P/E ratio and Profitability. Journal of Business and Economics Research, Vol. 12, No. 1, 67-76

Williams Equity Research. (2015). The Molodovsky Effect: A better understanding of the P/E ratio. Seeking Alpha. Retrieved from: https://seekingalpha.com/article/3500726-molodovsky-effect-betterunderstanding-p-e-ratio

Yuanlong, H. (2012). Relationship between Firm's PE Ratio and Earnings Growth Rate. University of Cincinnati. UMI Dissertation Publishing. 


\section{Appendix}

Appendix 1: Abbreviations Used and Definition of Terms

\begin{tabular}{|l|}
\hline ATO - Asset Turnover \\
BSP - Bangko Sentral ng Pilipinas \\
DCF - Discounted Cash Flow \\
DPO - Dividend Payout \\
EPS - Earnings per Share \\
FCFE - Free Cash Flow on Equity \\
GDP - Gross Domestic Product \\
NYSE - New York Stock Exchange \\
PBV - Price-Book Value \\
PER - Price-Earnings Ratio \\
PSA - Philippine Statistics Authority \\
PSE - Philippine Stock Exchange \\
ROA - Return on Assets \\
ROCE - Return on Capital Employed \\
ROE - Return on Equity \\
SPSS - Statistical Package for the Social Sciences \\
Pearson Correlation - a statistical measure of relationship between two variables ranging from -1 \\
(strong negative correlation) to +1 (strong positive correlation) \\
P/PeakE - Price-Peak Earnings Multiple, an alternative measure of PER by which the current share \\
price is divided by the highest earnings per share achieved over a specific period. \\
Tobin's Q - the ratio of a firm's assets' market value over its replacement value
\end{tabular}

